\title{
Controversial Status of Objective Resolution in the Form of Article 2A in the Constitutional History of Pakistan
}

\author{
Dr. Juliana Usman Wachani \\ Lecturer \\ Raunaq e Islam Government Gils College \\ Kharadar, Liyari- Karachi \\ juliyanausman13@gmail.com \\ Prof. Dr. Sameena Saeed \\ Department of Political Science \\ University of Karachi \\ dr.saminasaeed@gmail.com
}

\begin{abstract}
Everyone is familiar that the purpose of acquisition of Pakistan is to establish an Islamic state. Under this perception the objectives resolution was presented by the first Prime Minister of Pakistan Liaquat Ali Khan before the first constituent assembly of Pakistan on $7^{\text {th }}$ March 1949, which was approved on $12^{\text {th }}$ march. It is the preamble of the constitution of Pakistan 1973 and has been made it's an operative in 1985 under article 2A. Consequently amongst all the constitutions of Pakistan, the objective resolution worked as a foundation stone. The aim of the research is to understand the significance of the Article 2A. The qualitative method has been used to achieve the following intentions. The findings has depict the reality of Status of Article $2 A$ is controversial and it should be revised in the constitution of Pakistan.
\end{abstract}

Key words: Objective resolution, Islam, Article 2A, constitution of Pakistan. 


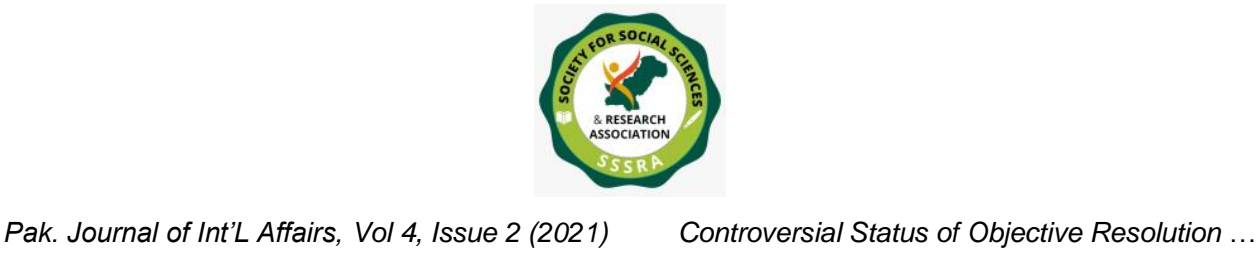

\section{Introduction:}

The emergence of Pakistan on the map of world is not merely a coincidence. In fact a tough struggle is hidden behind its establishment. Like other states the independence story of Pakistan is not only to acquire a piece of land or to establish a state and run it on worldly political system. But instead of this the leaders of the movement of Pakistan had the ideology to establish an Islamic welfare state. They wanted to establish a state that works on the line of Shariah and for the welfare of the people.

In this scenario, the leaders of $1^{\text {st }}$ constituent assembly under the leadership of then and their Prime Minister Liaquat Ali Khan presented objective resolution on $7^{\text {th }}$ March 1949.

According to the principles of objective resolution: (Mehdi, 2013)

- Sovereignty belongs to Allah.

- Rulers of the country are the representatives of Allah and they will serve for the people of Pakistan under the commandments of almighty Allah.

- Constituent Assembly shall frame the constitution of Pakistan.

- Chosen representatives shall exercise the authority of the state.

- Shariah will be the supreme law of the country.

- The principles of freedom, democracy, equality and justice enunciated by Islam shall be enforced throughout the county.

- According to the teachings of Islam Muslims shall lead their lives.

- Minorities shall be given freedom to profess and practice their religion.

- Federal form of government shall be enforced in the country and all the units will enjoy provincial autonomy.

- All Citizens of the state shall be treated equally and enjoy equal legal status. They will enjoy fundamental rights including economic and political justice. They are free to express their thoughts, ideas, belief, worship and faith and make association as par subject to law.

- Safeguard to the sovereignty of the country and integrity of the territory shall be ensured.

- There is a silver line that the people of Pakistan will enjoy honored place amongst the nations of the world by the virtue of their positive role in maintain peace, progress and welfare of humanity. (Fifth Session of the Constituent Assembly of Pakistan) 


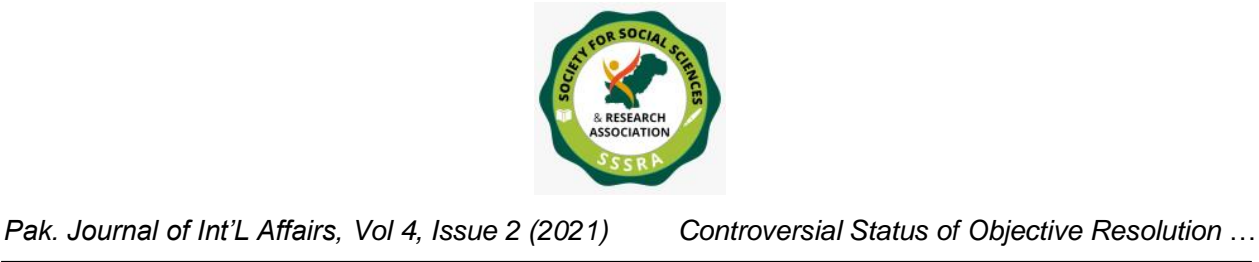

- This resolution was opposed by leaders of the opposition. However all the members of opposition were in the minority. There were the Hindus belonged to the East Pakistan and fewer in number. While the Muslim members were in majority. Eventually objective resolution was approved unanimously on $12^{\text {th }}$ March 1949 by the first constituent Assembly under the premiership of Liaquate Ali Khan. Mr. Liaquate Ali Khan at the time of moving objective Resolution emphasized on two points:-

Firstly He appreciated the Islamic character of objective resolution.

Secondly he warned that the purpose of objective resolution has no means to enforce clergy government. As there is no room for clergy governing model in Islam and it was neither practiced by The Holy Prophet (p.b.u.h) nor by his pious caliphs (R.A).

In this perspective, one could drive that Pakistan is an Islamic state and it was the dream of the leaders of the movement of Pakistan that to establish such kind of state, where political system could be administer on the pattern of Islam.

He categorically uncovered the intentions of the framers that this resolution incorporates those leading principles on which the foundation of the constitution of Pakistan will lie. He justified about the move of the objective resolution that people of Pakistan struggled for acquiring a separate country, because they wanted to have the piece of land where they can lead their life according to the teachings of Islam. In this connection it is the dire need of time to frame the guiding principles for future constitution on the Islamic lines.

Minorities had no objection on the contents except the Islamic character of the resolution. But their all fears were dispelled by the arguments of Mr. Liaquate Ali Khan, Mr. Ishtiaque Hussain Quraishe and Moulana Shabbir Ahmed Usmani.

Dr. Ishtiaque Hussain Quraishe guaranteed that the resolution embodies political and legal limitations on the structure of government and it will provide shelter to minorities. He introduced a unique kind definition of secular. That the government which is not theocratic is secular. Islam doesn't support any theocracy /clergy. Thus the embodying principles of democracy proposed by this resolution, by definition are secular.

Moreover Moulana Shabbir Ahmed Usmani supported the objective resolution that Pakistan is an Islamic state and acquired in the name of Islam. In this respect almighty 


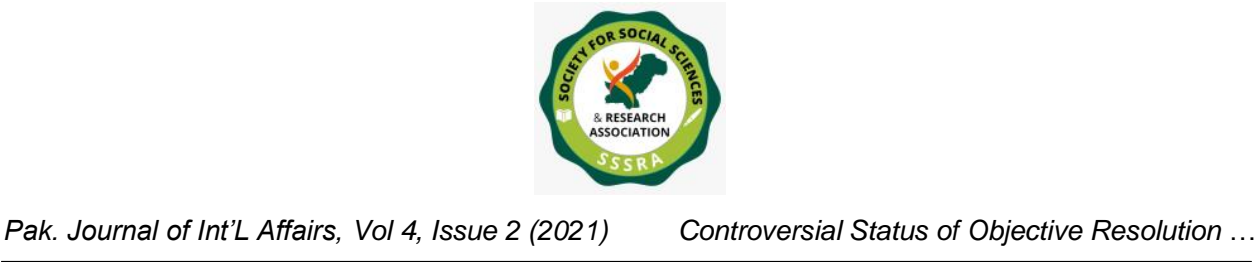

Allah has imposed duty upon the Muslim masses of Pakistan to protect the rights of nonMuslims in their all aspects of life. That is how they allayed the fears of opposition. (2)The objective resolution acted as a preamble of the constitution in all the constitutions of Pakistan. It is regarded as the foundation stone for the constitution of Pakistan. In the light of the principles of objective resolution the law makers promulgated three constitutions of the state. But in 1985 the status of objective resolution was changed by then and there president General Zia ul Haq and objective resolution became an operative part of the constitution in the form of Article 2A.

\section{Literature Review:}

Ahmed Umair in "The evolution of the role of the objective resolution in the constitutional Paradigm of Pakistan-from the framers' intent to a tool for judicial overreach." states that the role of the objective resolution is not to trampling on the rights of minorities, but the main purpose of this resolution is to ascertain guiding principles of the future constitution and to ensure the people of Pakistan that the very aim of this newly state has been fulfilled. The pioneer leaders of the objective resolution ensured minorities that passing of this resolution is not to make Pakistan a theocratic state. As theocracy has not been acknowledged in the political system of Islam. It has neither been practiced by Holy Prophet (p.b.u.h) nor by the pious caliph (R.A).

Farukh Deyya (2016) in an article "A critique on the article 2A of the constitution." states that there is a great apprehension that Article $2 \mathrm{~A}$ is curtailing fundamental rights particularly with regard to women and minorities. Under this article Hudood ordinance 1979 was enforced throughout the country which incarcerated countless women who leveled accusation of rape and adultery on any male and failed to produce four witnesses.

Ahmed Jaffer Sayed Dr. (2019), in his article 'Objective Resolution Deviation from Quid e Azam's Vision' 'discusses that Article 2A has been made an operative part of constitution. But after making it an operative part by a planned scheme the word "freely" was missing and this was not an accidental mistake. By missing this word the intent of the framers of eighth amendment was to attack on the religious rights of minorities. And this missing word was not noticed by the parliament until 2010. This was total deviation from the vision of the founder of Pakistan Quid e Azam Mohammad Ali Jinnah. 


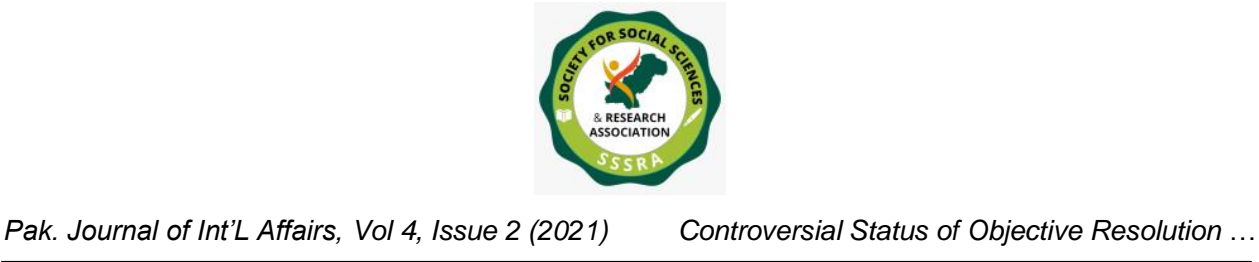

Under Article 7(1) of Muslim Family Law ordinance 1961 when husband divorces his wife. He has to deliver notice to the chairman of the Union council and as well as supply the copy of divorce to his wife.

(Mst. Kaneez Fatima V. Wali Mohammad PLD 1993 SC 901) case has been taken as a precedent that Wali Mohammad failed to deliver notice to the chairman of the Union Council and supply copy to his wife Kaneez Fatima. On this failure wife filed suit of maintenance.

(Asma Jillani VS. Government of Pakistan: Case PLD 1972) has been taken as a precedent that the Military dictator has not won the country. The arrest of Malik Ghulam Jillani, who was the father of Asma Jillani, His arrest was considered illegitimate. As apex court passed remarks that CMLA is not a victor or Pakistan is not an alien territory that was won by him. Pakistan has its own legal code, has objective resolution. Thus objective resolution was given the status of grundnorm.

(Hakim Khan VS Government of Pakistan. PLD 1992SC595) has been adopted as a precedent that the President Using his power on the advice of Prime Minister under Article 45 of the constitution of Pakistan has remitted and reprieved the sentences of those prisoners whose punishments were declared in military regime. Hakim Khan challenged Article 45 in the light of Article 2A.

Article 3 and Article 17 of the Qanoon e Shahadat Order 1984 discusses that according to Islamic law the witness should fulfill all the qualities of Tazkiyat ul Shahood and he must not be involved in any major or minor sin (Article 3 and Article 17 of the Qanoon e Shahadat Order 1984).

Lau, Martin (2007) in "Twenty-Five Years of Hudood Ordinances- A Review" argues that implementation of Hudood ordinance was tough time for Pakistani women. It has become very easy for a male to involve in the case of adultery to any woman. Women were facing critical time as they were not able to obtain bail from trial court and the court of filing appeal was Sharia.

\section{Research Questions:}

- What is the status of objective resolution in the constitution of Pakistan? 


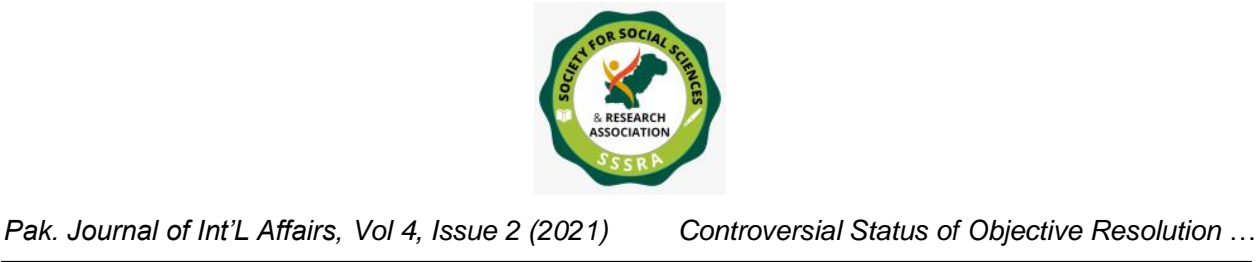

- What was the real intention of the framers of the objective resolution as regard to its approval?

- Is the objective resolution a supra constitutional document in the system of justice of Pakistan?

- To what extent the text of objective resolution justifies the fears of minorities?

- Should Article 2A be incorporated as a provision in the constitution of Pakistan?

\section{Methodology:}

The study is routed in qualitative method to analyses the controversial status of objective resolution in the constitutional history of Pakistan after making it an operative part of the constitution in the form of Article 2A. For collecting data of this research study qualitative approach has been adopted. The nature of collected data is of secondary sources. In this connection data has been gathered from books, research journals and articles from various newspapers.

\section{Article 2A:}

General Zia ul Haq was a military dictator. For legitimizing his ruler he covered himself with the shield of Islam. Thus he changed the status of objective resolution which was envisaged by the framers of resolution.

According to Article 2A the objective resolution became the substantive part of the constitution. In following words in the form of Article 2A the objective resolution has been given the status of an operative part of the constitution.

"The principles and provisions set out in the Objective Resolution reproduced in the Annex are hereby made substantive part of the Constitution and shall have effect consequently. (Ahmed 2008),

Inclusion of this provision made operative all the provisions of the Objective Resolution. Subsequently the position of objective Resolution was replaced from preamble to the substantive part of the constitution.

Many aspects of Article 2A were criticized on various occasions. This criticism made the status of Article 2A controversial. This criticism was leveled upon following grounds. 


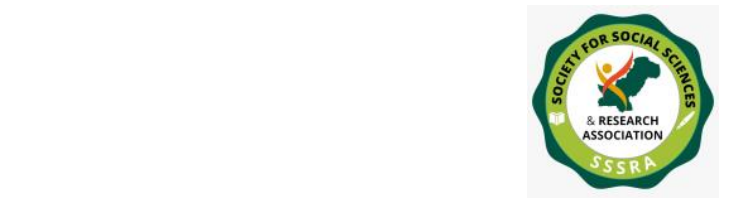

Pak. Journal of Int'L Affairs, Vol 4, Issue 2 (2021)

Controversial Status of Objective Resolution ...

\section{Contrary to the Intent of the Framers of the Objective Resolution}

Objective Resolution was presented on $7^{\text {th }}$ March 1949 and it was approved on $12^{\text {th }}$ March 1949. Up to five days from $7^{\text {th }}$ March to $12^{\text {th }}$ March a debate continued among the members of constituent Assembly. As non-Muslim members who were less in numbers and constituted minority, expressed their concern that approval of this resolution will convert the state into a theocratic state, But Muslim leaders justified their move of objective resolution that the object of passing objective resolution is only to ensure the people that the purpose which was envisaged by them to establish an Islamic State have been fulfilled without intermeddling the rights of minorities.

All the members of opposition and government are on the same page about the status of objective resolution that the visualized principles in the objective resolution are meant to provide guideline for promulgation of future constitution instead of making it an operative part of the constitution or a supra constitutional document. It would merely act as a guideline document.

Following the intentions of the framers objective resolution was given the status of preamble on all three constitutions of Pakistan. i.e. constitution of 1956, constitution of 1962 and constitution of 1973. Thereafter in 1985 a dictator for legalizing his dictatorial rule took the shelter of Islam and changed the status of objective resolution and made it the substantive part of the constitution. His act was totally in contrast with the intention of the framers of the objective resolution and caused many constitutional complications. (Malik, 1996).

\section{Contrast between Theory and Practice}

The Objective resolution embodies the principles of democracy, freedom, tolerance and equality and these all golden principles will be practiced as par the definition of Islam. The resolution recognized that sovereignty belongs to Allah, who will be the supreme authority and will be superior to all political, judicial and philosophical authority. Likewise resolution authenticates that people of Pakistan will lead their lives according to the injunctions of Islam and the system of the country will be governed according to the political system of Islam. This is the main theory of the objective resolution in which Islam was highlighted in each principle of resolution. 


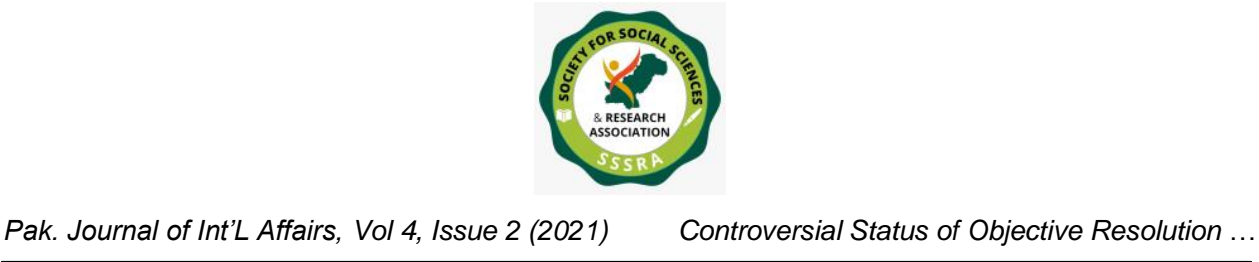

But the practice is quite different. On the one hand Islamic political system has been given superiority; meanwhile on the other hand federal parliamentary system has been introduced. One can easily drive that theory and practice are contrast to each other.

Similarly it has been categorically stated in the objective Resolution that the rulers of the state will be representatives of almighty Allah and will exercise their powers within the limits prescribed by Allah. Making objective resolution as an operative part raises the question that who will prescribe those limits. No authority has been mentioned. As Article $2 \mathrm{~A}$ is the production of a dictator. It all shows that the prescribed limits will be defined by a military dictator. This is unacceptable for a country which is great exponent of democracy. Thus the position of Article 2A has become controversial. (Farukh 2016)

\section{Misuse of Article 2A Curtailed Religious Freedom of Minorities}

In all three constitutions of the country, the constitution of 1956, the constitution of 1962 and the constitution of 1973 respectively, objective resolution was incorporated as a preamble of the constitution. But in 1985 the system of political governance was changed and semi presidential form was introduced in the political system of Pakistan by introducing eighth amendment in the constitution of Pakistan.

The founder of Pakistan, Quaid e Azam Mohammad Ali Jinnah declared constituent Assembly as a sovereign institution in his popular speech delivered on August $11^{\text {th }}, 1947$. In that speech he guaranteed that minorities are free to practice their religion. Using the tool of eighth amendment Article 2 and Article 2A were made substantive parts of the constitution and intentionally the words "freely" was omitted as regard to the religious freedom of the minorities.

This was a very shocking fact that even comma and full stop when need to be removed it from any law, it requires amendment by the two third majority of parliament. But this is regrettable that parliament of Pakistan was too much negligent that until $18^{\text {th }}$ amendment (2010) no parliament of Pakistan noticed the missing word "FREELY". And it was the complete deviation from the vision of Quaid e Azam Mohammad Ali Jinnah and intentions of the framers of the objective resolution. (Hassan, 1985)

\section{Judicial Dilemma and Article 2A}




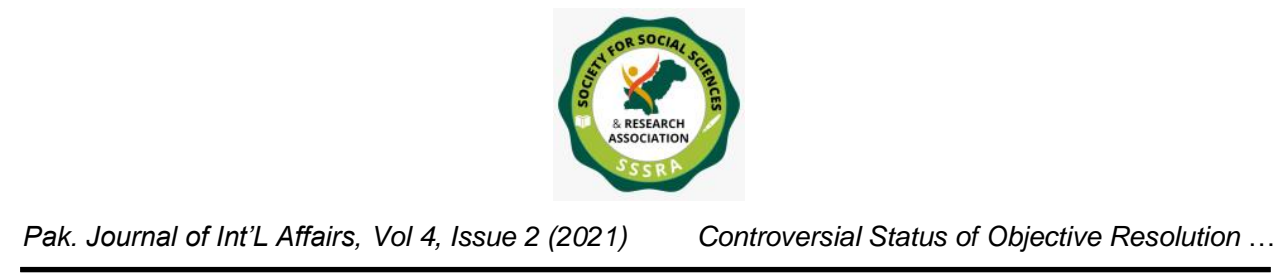

Judicial history of Pakistan has witnessed many cases which raised questions about the controversial status of Article 2A. Precedents in this connection are herein below.

In Mst. Kaneez Fatima V. Wali Mohammad PLD 1993 SC 901case, Mr. Wali divorced her wife Kaneez Fatima. According to section 7(1) of Muslim family Law Ordinance he was bound to give notice to the chairman of the Union Council and supply the copy to his wife.

But Mr. Wali failed to do so. On the basis of this failure Mst. Kaneez Fatima filed suit of maintenance against her husband and maintained arguments that Talaq has not been revoked but it may only be ineffective. (Kaneez 1993) Section 7(2) also provides that whoever contravenes section 7(1) of Muslim Family law ordinance 1961 he is liable of imprisonment for a term which may extend to one year or fine which may extend to 5000 rupees or both. The same procedure mentioned in section $7^{\text {th }}$ of Muslim Family law and ordinance is applicable on Talaq e Tafwid (Delegated Divorce) in Pakistan. This has total contrast to Islamic Law. According to Islamic law once divorce is pronounced by husband, from the same moment it comes into effect. The effects of divorce as par the law of Islam cannot be suspended by any human authority/law. Thus this case caused contradiction between Article 2A and section $7^{\text {th }}$ of Muslim Family Law ordinance 1961. (The Muslim Family Laws Ordinance)

Following points arose in this case in the context of Article 2A:

- To determine the status of Article 2A.

- To determine the fact that it is the preamble of the constitution.

- Does it own the position of supra constitutional document?

- Is it overriding other articles? (Kaneez 1993)

Thus the status of article $2 \mathrm{~A}$ became controversial for apex court in this case.

Similarly Hakim Khan V Government of Pakistan (PLD 1992SC595) is another series of this study.

In 1988 the Ex-President of Pakistan on the advice of Benazir Bhutto, commuted all the death sentences pronounced by the military courts on the order of the Ex-Prime Minister. The President of Pakistan according to Article 45 used his authority and commuted all 


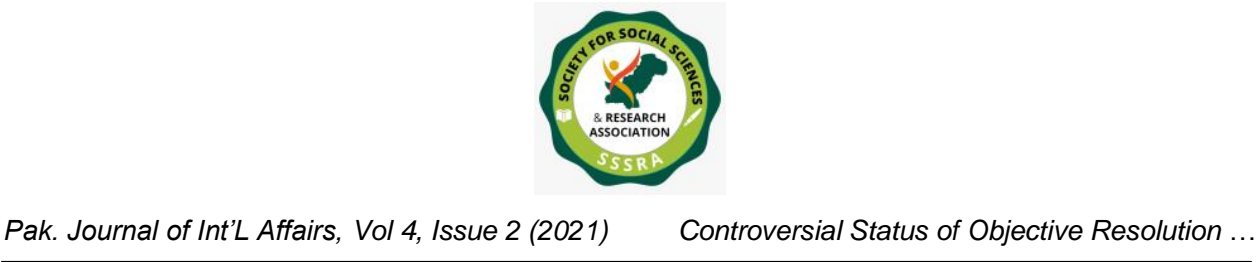

death sentences awarded by the military courts. Hakim Khan raised the point that this order was contrary to Article 2A. Article 2A of the constitution of Pakistan. It provides that Almighty Allah is the supreme authority and he only enjoys the authority to commute or waive the death sentence. While Article 45 of the constitution of Pakistan confers authority to the president of Pakistan that he can commute, pardon, reprieve and remit any sentence. The prior position of objective resolution was also discussed when the objective resolution merely had the status of preamble. Thereafter it became an operative part of the constitution by General Zia ul Haq. Similar points were in questions which were also raised in Hakim Khan Case. As such

- What is the status of article 2A?

- To discover the correct position of Article 2A that whether it is preamble or an operative part of the constitution?

- Does Article 2A is superior to the constitution of Pakistan?

- Does Article 2A dominating other articles of the constitution of Pakistan?

The court held that though Article 2A has become operative part of the constitution but yet it cannot be considered supra constitutional document. A full bench of the High Court accepted this ground that only Wali (guardian) as par the injunctions of Islam is authorized to waive Qisas. But Supreme Court against this verdict accepted appeal that Court has no authority to declare any provision null and void. This is the issue of Parliament and the parliament of Pakistan need to tackle it after taking notice of it. Thus it is out of the jurisdiction of court to knock down Article 45, even it is repugnant to the injunctions of Islam. Hence it was decided by the court that it is beyond the jurisdiction of the court to knock of any provision by invoking article 2A. (Hakim Khan VS. Government of Pakistan)So in this respect the efficacy of Article 2A was lost.

However in Asma Jillian's case the arrest of the Mr. Glulam Jillani was declared illegitimate. As this order was passed in the regime of Martial Law administrator General Yahya Khan. The court passed its verdict on the grounds that Pakistan was not a foreign/alien territory that was won by Chief Martial Law Administrator .Similarly the orders issued by a military man are not supra constitutional. Pakistan is not without law; it has its own legal code, the Holy Quran and objective Resolution. In this case Objective resolution was given the status of grundnorm. (Asma Jillani VS. Government of Pakistan) 


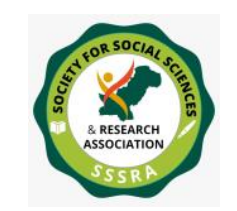

Pak. Journal of Int'L Affairs, Vol 4, Issue 2 (2021) C Controversial Status of Objective Resolution ...

\section{Usurpation of Fundamental Right by Article 2A}

The fundamental rights which are mentioned from Article $8^{\text {th }}$ to Article $28^{\text {th }}$ in the constitution of Pakistan. These fundamental rights are endowed by state to its subject so as they can enjoy freedom. But Article 2A usurped these rights. Islamic tents were misused in the form of article 2A. After taking the shelter of Article 2A by a military dictator the golden principles of Islam were misinterpreted. The fundamental rights as regard to women were replaced with Hoodooed Law ordinance 1979, which was enforced by a military dictator General Zia in 1979. According to Hudood ordinance any woman who levels charges against a man and declare herself as a victim of rape she has to produce four witnesses. In case of non-presence she would be kept behind the bar. (Hudood Ordinance 1979)

By the virtue of Article 2A this law was enforced. As Islam requires four witnesses if one levels accusation against any other person. Islam is the religion of all times. It is the modern religion. There are so many other sources in todays advanced science and technology era. The allegation of rape could be investigated by other modern devices and new methods of investigation as such circumstantial evidence, forensic report, DNA test. Even the rape case could be investigated by collecting biological evidences as such semen, blood, vaginal secretions; saliva etc. But Hudood ordinance by the virtue of Article $2 \mathrm{~A}$ confined rape cases merely to the evidence of four men. It seemed that General Zia had lack of knowledge about Islam. Because the witnesses have to fulfill the conditions of Tazkiyat ul Shahood according to article 3 and 17 of Qanoon e Shahadat order 1984.In short, meeting the condition of Tazkiyat ul Shahood means any witness who did not commit any minor or major sin throughout his life. (Qanoon e Shahadat order 1984 Article 3 \& 17.)

May we find such kind of witness in Pakistan! The answer is negative. It shows that enforcement of Hudood ordinance was not to enforce the laws of almighty Allah but only to usurp the right of the women and she is weak entity of our society.

When Hudood ordinance was enforced with its full spirit. Number of women was incarcerated. As they failed to produce witnesses. It was considered a great sin if anybody enters into debate against Hudood ordinance. The cases of adultery and rape were the 


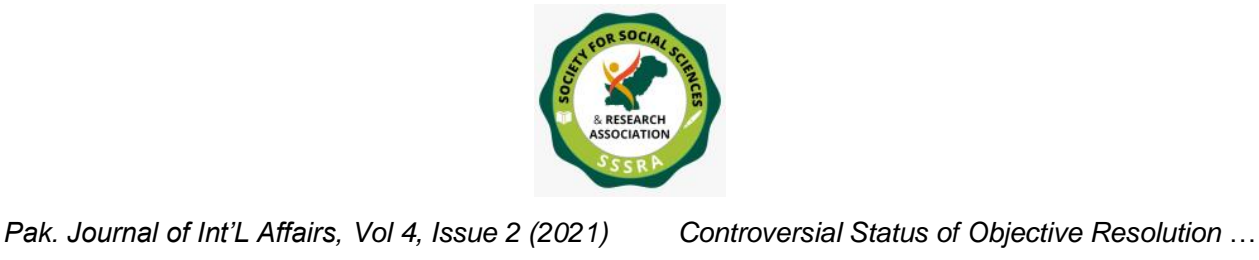

subject of Shariah law and the trial of these cases were to be conducted by the session court and appeal against the order of session court was laid at Federal Shariah Court.

According to legal scholar Martin Lau

While it was easy to file a case against a woman accusing her of adultery, the Zina Ordinance made it very difficult for a woman to obtain bail pending trial. Worse, in actual practice, the vast majority of accused women were found guilty by the trial court only to be acquitted on appeal to the Federal Shariah Court. By then they had spent many years in jail, were ostracized by their families, and had become social outcasts." (Lau,2007)

Against this bill number of suggestions was put forward by the government appointed commission. Finally after the struggle of 27years on $15^{\text {th }}$ November 2006 National Assembly passed women protection Bill. It was heavily criticized by religious parties. As new law ceased the condition of production of four witnesses for a woman victim of rape. And for the trial of rape cases other sources as such forensic report and circumstantial evidence will be taken into account. The rape cases were brought under Pakistan panel code instead of Sharia Law. Under this bill the investigation of rape cases are done as par modern methods of investigation. Police is not authorized to keep behind the bar if it finds any couple at outside. They will be brought before the court and the court will decide their destiny on the basis of evidence.

Thus Article 2A became controversial again as regard to the rights of women. Because its object was not to implement the law of almighty Allah but in the name of Islam he wanted to give invalidated length to his sovereignty.

Article $2 \mathrm{~A}$ is causing another problem for law makers. They are worried that what law should be brought under Pakistani law and what law should be brought under Shariah law.

Confusion is being created due to article 2A that what law should come within the limits of Pakistani law. Such as the protection of women against violence bill that was approved unanimously by Punjab Assembly. The object of bill was to protect women against domestic violence, acid attack and rape, economic and psychological abuse. All those criminal actions which can be applied against women. Women were given protection in 


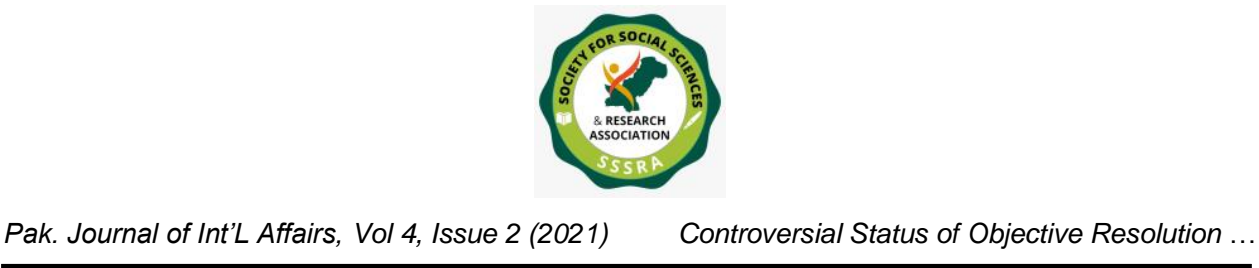

the form of this bill. But the clerics declared this bill un-Islamic. This bill was considered as death of family system.

But the question arises that does Islam allow domestic violence?

Does Islam allow throwing acid on the faces of women and deforming their attractive faces?

Does Islam allow rape of women?

Does Islam permit man to beat violently to any women?

Definitely not! Islam is the religion which has given respectful status to the woman. It has very first time given women the share in property. It was Islam that has forbidden burying the innocent female child alive.

How clerics could declare any law anti-Islamic that prohibits violence, acid attack, and rape, economic and psychological abuse. The clerics raise their undue protests due to presence of article $2 \mathrm{~A}$.

\section{Findings}

Findings of research study are listed below.

- Islam has been misinterpreted in the in the form of Article 2A.

- Various running laws in the judicial system of Pakistan are contradictory to Article 2A.

- Article $2 \mathrm{~A}$ is the production of a dictator. Its role like a shelter and under the disguise of this shelter a dictator extends his tenure and power.

- Judiciary of Pakistan failed itself to decide the status of Article 2A.

- Status of Article 2A is controversial and it should be revised in the constitution of Pakistan. (Ziring, 1997) 


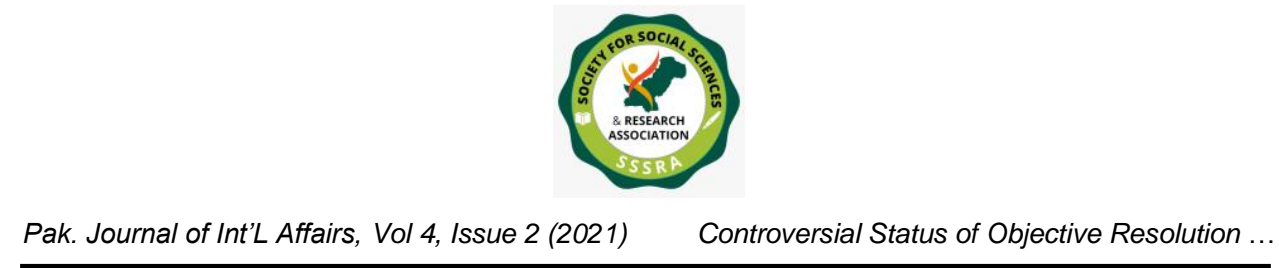

\section{Conclusion}

Article 2A presents incorrect picture of Islam. This does not denote the real picture of Islam. Indeed it has been misused by a dictator in the name of Islam.

Islam is a modern religion. It possesses the feature of adjustability and adaptability according to the all circumstance of modern time. It is not the religion of ancient period which remains intact. In the light of holy Quran and Sunnah new laws can be framed. The care that is only required it is not to make any law that is contrary to the injunctions of Islam. Even in the pre Islamic era those laws were not abolished that had not imparted negative impacts on the lives of the people. Only those laws were repealed which had negative effects on the society.

In this respect the presence of article $2 \mathrm{~A}$ is not the guarantee of establishing an Islamic state. To make Pakistan an Islamic state it is necessary to make serious efforts in this regard and to adopt Islamic injunction in all the fields of life.

Currently the governance and legal system of Pakistan is neither called Islamic nor western. Once our pioneer leader wanted to establish an Islamic state, while practically they have set up the political system of Pakistan on western system. Similarly our legal system is mostly comprised of English legal system. In courts criminals are punished according to the provisions of Pakistan Penal code and proceedings are conducted according to CRPC (Criminal procedure code. There are so many other acts which are not Islamic as such contract act, partnership act, company law etc. 


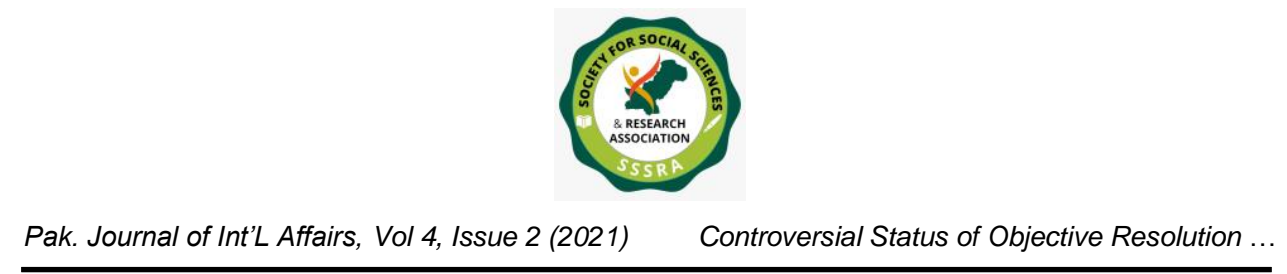

\section{Reference}

Mehdi, R. (2013). The Islamization of the Law in Pakistan (Rle Politics of Islam). Canada and United States of America. Routledge.

Fifth Session of the Constituent Assembly of Pakistan, Official Report, $5^{\text {th }}$ Volume 1949 from $7^{\text {th }}$ to $12^{\text {th }}$ March 1949.

Ahmed U. (2008), The evolution of the role of the objective resolution in the constitutional Paradigm of Pakistan from the framers' intent to a tool for judicial overreach. Lums Law Journal Volume V., 51-53.

H. Malik, I. (1996). State and Civil Society in Pakistan: Politics of Authority, Ideology and Ethnicity. New York, United States of America. Macmillan Press Limited and St. Matrin's Incorporation.

Farukh Deyya, "A critique on the article 2A of the constitution". Courting the Law, September $7^{\text {th }}, 2016$.

Hassan, R. Islamization: an Analysis of Religious, Political and Social Change in Pakistan. Middle Eastern Studies. 1985. 21. (3).

Mst. Kaneez Fatima V. Wali Mohammad PLD 1993 SC 901.

The Muslim Family Laws Ordinance 1961 (VIII of 1961).

Optic, Mst. Kaneez Fatima V. Wali Mohammad PLD 1993 SC 901.

Hakim Khan VS. Government of Pakistan. (PLD 1992 SC595).

Asma Jillani VS. Government of Pakistan: Case PLD 1972.

Hudood Ordinance 1979.

Qanoon e Shahadat order 1984 Article 3 \& 17.

Lau, Martin ( $1^{\text {st }}$ September 2007). "Twenty-Five Years of Hudood Ordinances- A Review". Washington and Lee Law Review. 64 (4): 1292. Retrieved $18^{\text {th }}$ November 2014.

Ziring, L. (1997). Pakistan in the Twentieth Century: A Political History. Karachi, Pakistan. Oxford University Press. 